Ezra Krisna, Septia Winduwati: Strategi Komunikasi Lembaga Bimbingan Belajar dalam Mempertahankan Loyalitas Pelanggan pada Masa Pandemi (Studi Kasus Pada Bimbel Timothy's)

\title{
Strategi Komunikasi Lembaga Bimbingan Belajar dalam Mempertahankan Loyalitas Pelanggan pada Masa Pandemi (Studi Kasus Pada Bimbel Timothy's)
}

\author{
Ezra Krisna, Septia Winduwati \\ ezra.915170033@stu.untar.ac.id,septiaw@fikom.untar.ac.id
}

Fakultas Ilmu Komunikasi Universitas Tarumanagara

\begin{abstract}
Bimbel Timothy's is a non-formal tutoring institution that was formed to assist customers to understanding the learning materials provided by formal educational institutions. This research using strategy communications as the concept, that is the combination of communication planning with the communication management to achieve the goals. This study uses a qualitative research approach with data collection methods using interview techniques, documentation studies, and literature studies. The result of this research is Bimbel Timothy's using communication strategy which is planning, implementation and evaluation of the communication strategy that implemented by Bimbel Timothy's during the COVID-19 pandemic in order to maintain customer loyalty. Of the entire series of communication strategies which is planning, implementation and evaluation that implemented, the role word of mouth is a technique used so that customers continue to trust business institutions during the COVID-19 pandemic.
\end{abstract}

Keywords: bimbel timothy's, communication strategy, customer loyalty

\begin{abstract}
Abstrak
Bimbel Timothy's merupakan salah satu lembaga bimbingan belajar non-formal yang dibentuk guna membantu pelanggan dalam memahami materi pembelajaran yang diberikan oleh lembaga pendidikan formal. Konsep yang digunakan pada penelitian ini adalah strategi komunikasi yang merupakan paduan perencanaan komunikasi dengan manajemen komunikasi untuk mencapai tujuan yang telah ditetapkan. Penelitian ini menggunakan pendekatan penelitian kualitatif dengan metode pengumpulan data yang menggunakan teknik wawancara, studi dokumentasi, dan studi kepustakaan. Hasil penelitian ini adalah Bimbel Timothy's melakukan strategi komunikasi yang terdiri atas proses perencanaan, pengimplementasian serta evaluasi dari strategi komunikasi yang diterapkan oleh Bimbel Timothy's pada masa pandemi COVID-19 agar tetap dapat mempertahankan loyalitas pelanggannya. Dari seluruh rangkaian strategi komunikasi antara lain perencanaan, implementasi, dan evaluasi yang diterapkan, peran word of mouth merupakan teknik yang digunakan agar pelanggan tetap percaya terhadap lembaga usaha pada masa pandemi COVID-19.
\end{abstract}

Kata Kunci: bimbel timothy's, loyalitas pelanggan, strategi komunikasi

\section{Pendahuluan}

Pendidikan merupakan suatu aspek penting pada kehidupan masyarakat. Hal tersebut didukung oleh Kementerian Pendidikan dan Kebudayaan (Kemendikbud) pada website Kemendikbud.go.id yang menyatakan bahwa pemerintah membuat program wajib belajar 12 tahun dengan melaksanakan Program Indonesia Pintar 
(PIP). Hal tersebut dikemukakan dengan tujuan $\mathrm{t}$ meningkatkan akses bagi siswa yang berusia 6 sampai 21 tahun untuk menempuh pendidikan hingga tamat satuan pendidikan menengah serta mencegah bagi peserta didik agar terhindar dari kemungkinan putus sekolah.

Pendidikan juga diharapkan dapat membangun siswa agar menjadi pribadi yang memiliki tingkat moralitas yang tinggi. Tujuan lain dari adalah memberikan ilmu yang meningkatkan mutu pengetahuan siswa. Siswa yang sedang menempuh pendidikan, umumnya masih memiliki emosi yang belum stabil dan sangat kritis dalam menanggapi suatu hal. Hal ini tentunya membutuhkan bimbingan seorang guru.

Proses bimbingan yang dilakukan oleh seorang guru merupakan proses penyampaian pengetahuan kepada siswa yang diajarkan. Menurut Donsu (2017), pengetahuan merupakan suatu hasil dari rasa keingintahuan melalui proses sensoris yang terdiri atas mata serta telinga terhadap suatu objek. Pengetahuan dapat membentuk perilaku yang terbuka. Oleh sebab itu, dengan memberikan pengetahuan kepada siswa diharapkan taraf hidup akan meningkat nya. Dalam upaya meningkatkan taraf hidup siswa, maka guru harus dapat membangun motivasi belajar siswanya agar setiap kegiatan pembelajaran dapat berperan untuk meningkatkan prestasi belajar siswa untuk mendapatkan pengetahuan yang maksimal. Dari motivasi belajar yang tinggi tersebut, siswa dapat meningkatkan intensitas usaha dan upaya yang yang dapat meningkatkan prestasinya.

Salah satu lembaga pendidikan non-formal yang dapat membimbing siswa agar dapat meningkatkan prestasinya yaitu melalui bimbingan belajar. Bimbingan belajar merupakan lembaga pendidikan yang dapat memberikan dukungan kepada perseorangan dengan tujuan untuk memperoleh ilmu pengetahuan serta kemampuan pribadi yang diperlukan dalam beradaptasi secara baik dan maksimal yang dapat diperoleh oleh siswa agar lebih berkompeten dalam menjalankan pendidikan di sekolah.

Bimbingan belajar dibentuk dengan tujuan agar dapat memberikan siswa kemudahan dalam mendapatkan ilmu yang diterima. Ia juga dihatapkan dapat memecahkan permasalahan dalam memahami materi pembelajaran yang diberikan di sekolah. Menurut Susanto (2018) secara umum bimbingan belajar dibentuk agar dapat mengukur kemampuan yang dimiliki oleh siswa, lalu menyusun aktivitas belajar serta agenda kerja, dan membantu meningkatkan potensi dalam diri siswa agar dapat berpiawai dalam menanggulangi permasalahan dalam proses pembelajaran.

Namun, karena pandemi COVID-19 sedang melanda dunia, maka sektor pendidikan juga terdampak akan hal tersebut. Dilansir dari situs kemkes.go.id, COVID-19 (coronavirus disease 2019) merupakan penyakit yang disebabkan oleh jenis coronavirus baru yaitu Sars-CoV-2, yang dilaporkan pertama kali di Wuhan, Tiongkok pada tanggal 31 Desember 2019. COVID-19 pada saat ini memiliki gejala gangguan pernafasan akut seperti demam lebih dari 38 derajat celsius serta batuk dan sesak nafas bagi manusia. Selain hal tersebut, gejala yang penderita alami dapat disertai lemas, nyeri otot, dan diare. Pada penderita COVID-19 yang berat, penderita dapat menimbulkan pneumonia, sindroma pernafasan akut, gagal ginjal, hingga kematian. COVID-19 dapat menular dari manusia kepada manusia lain melalui kontak erat dan droplet atau percikan cairan pada saat manusia bersin maupun batuk. Dikarenakan penyebaran COVID-19 cepat menyebar, maka kegiatan pendidikan yang seharusnya dilakukan secara tatap muka, akibat adanya pandemi COVID-19 
Ezra Krisna, Septia Winduwati: Strategi Komunikasi Lembaga Bimbingan Belajar dalam Mempertahankan Loyalitas Pelanggan pada Masa Pandemi (Studi Kasus Pada Bimbel Timothy's)

maka seluruh kegiatan pendidikan yang berbasis tatap muka harus diubah menjadi pendidikan dengan metode dalam jaringan (daring).

Pandemi COVID-19 sangat berdampak bagi sektor pendidikan yang harus mengubah seluruh sistem pendidikan baik formal maupun non-formal yang menggunakan metode pembelajaran tatap muka, sehingga bimbingan belajar sebagai salah satu cabang lembaga pendidikan juga harus mengubah metode pembelajaran daring. Metode pembelajaran daring yang terdapat pada lembaga pendidikan bimbingan belajar dirancang agar dapat dimungkinkannya proses pembelajaran jarak jauh melalui internet tanpa harus tatap muka dengan gurunya. Bimbingan belajar yang menggunakan metode daring dapat memberikan akses bagi siswa yang terhubung dengan koneksi internet agar dapat memperoleh layanan bantuan belajar yang efektif, efisien, serta interaktif dengan optimal (Enterprise, 2010)

Siswa yang mengikuti bimbingan belajar dengan metode daring diharapkan agar tetap dapat mempersiapkan diri dalam menghadapi ujian selain itu agar tetap dapat membantu para siswa agar lebih memahami materi pembelajaran yang telah diberikan oleh guru di sekolah. Proses komunikasi yang dilakukan selama penggunaan bimbingan belajar daring yakni dengan menggunakan audio, visual, maupun audiovisual. Komunikasi yang dilakukan tersebut agar siswa dapat memahami penyampaian pesan yang diajarkan oleh guru di bimbingan belajar tersebut.

Salah satu bimbingan belajar yang tetap bertahan pada masa pandemi COVID-19 di kawasan Cengkareng, Jakarta Barat adalah Bimbel Timothy's. Bimbingan belajar ini tetap melanjutkan aktivitas belajar mengajar dengan mengubah seluruh proses komunikasi tatap muka menjadi daring. Namun, dengan perubahan metode pembelajaran tersebut, bimbingan belajar memiliki dampak yang cukup serius. Hal tersebut dikarenakan banyak orang tua siswa sebagai pelanggan yang menganggap bahwa metode pembelajaran daring merupakan metode yang kurang efektif didapatkan apabila pengajaran dilakukan tidak dengan bertemu secara langsung antara siswa dengan gurunya. Hal inilah yang membuat bimbingan belajar merupakan sektor pendidikan non-formal yang sangat berpengaruh bagi keberlangsungan bimbingan belajar tersebut.

Strategi yang digunakan oleh Bimbel Timothy's yaitu dengan memberikan tenaga kerjanya fasilitas berupa layanan internet yang memadai sehingga guru dapat tetap mengakses berbagai informasi secara optimal walaupun dilakukan di rumah masing-masing. Selain itu Bimbel Timothy's menggunakan aplikasi e-learning yang terintegrasi yang memudahkan guru beserta siswanya untuk saling bertukar informasi. Hal tersebut memberikan kemudahan bagi guru kepada siswa dalam memberikan penjelasan mengenai materi pembelajaran yang akan dipelajari.

Dari dampak pandemi COVID-19 yang berpengaruh terhadap Bimbel Timothy's, maka peran strategi komunikasi sangatlah penting untuk diterapkan pada perusahaan yang berguna dalam membantu perusahaan agar dapat bertahan selama pandemi COVID-19.

Berdasarkan latar belakang masalah di atas, maka rumusan masalah pada penelitian ini adalah bagaimana strategi komunikasi Bimbingan Belajar Timothy's dalam mempertahankan loyalitas pelanggan pada masa pandemi COVID-19.

Penelitian ini dilakukan dengan maksud ingin mengetahui strategi komunikasi Bimbingan Belajar Timothy's dalam mempertahankan loyalitas pelanggan pada masa pandemi COVID-19. 
Kerangka pemikiran utama yang digunakan pada penelitian ini yaitu konsep strategi komunikasi. Strategi komunikasi menurut Savitri, Setyanto, dan Winduwati (2016), merupakan paduan perencanaan komunikasi dengan manajemen komunikasi untuk mencapai tujuan yang telah ditetapkan.

Strategi komunikasi dalam penerapannya juga memiliki tujuan yang terbagi atas to secure understanding yang merupakan upaya untuk memastikan bahwa komunikan mengerti dengan pesan yang diterimanya. Jika komunikan telah mengerti isi pesan yang disampaikan oleh komunikator, maka komunikan harus dibina, tahap tersebut dinyatakan to establish acceptance. Setelah komunikan telah terbina dalam menerima informasi yang diberikan oleh komunikator, maka akhirnya kegiatan komunikasi dapat dimotivasikan yang dinyatakan sebagai to motivate action (Effendy, 2011)

Menurut Anwar Arifin (Luthfiyah, 2016), komunikasi dilakukan oleh sebuah lembaga dengan tujuan dan target yang telah ditentukan, oleh sebab itu penerapan strategi komunikasi perlu untuk dilakukan agar dapat menentukan langkah-langkah yang tepat dalam mencapai tujuan yang diinginkan. Langkah-langkah tersebut antara lain mengenal khalayak, menyusun pesan, menetapkan metode, seleksi dan penggunaan media, peranan komunikator, dan evaluasi.

Lalu, dari strategi komunikasi yang ditetapkan tentunya memiliki tujuan agar perusahaan dapat mempertahankan loyalitas pelanggannya. Menurut Mokodogan, untuk mendapatkan pelanggan yang loyal, maka perusahaan harus membutuhkan waktu yang panjang dalam membangun kepercayaan pelanggan tersebut. Waktu yang panjang tersebut dapat menciptakan kesempatan bagi perusahaan dalam mengajak pelanggan dalam melakukan pembelian produk secara berulang. Hal tersebut dapat membuat perusahaan mampu menciptakan pelanggan yang loyal terhadap perusahaan tersebut (Masuroh, 2020).

\section{Metode Penelitian}

Peneliti menggunakan pendekatan penelitian kualitatif dengan metode penelitian studi kasus yaitu meneliti secara mendalam mengenai kondisi perusahaan Bimbel Timothy's dalam mempertahankan loyalitas pelanggan pada masa pandemi COVID-19. Teknik pengumpulan data yang peneliti gunakan yaitu teknik wawancara kepada narasumber agar mendapatkan informasi tentang strategi komunikasi yang digunakan oleh Bimbel Timothy's pada masa pandemi COVID-19 dalam mempertahankan loyalitas pelanggannya, serta didukung dengan studi dokumentasi dan studi pustaka guna menyempurnakan penelitian ini. Teknik analisis data yang digunakan oleh peneliti yaitu dengan melakukan reduksi data, penyajian data, dan conclucion drawing atau verification. Serta teknik keabsahan data menggunakan teknik triangulasi sumber yang mengacu pada hasil wawancara, studi pustaka dan dokumen dalam mengumpulkan data.

\section{Hasil Temuan dan Diskusi}

\section{Komunikasi Bimbel Timothy's Kepada Pelanggan terhadap Prosedur Bimbingan Belajar}

Menurut Savitri, Setyanto, \& Winduwati (2016), strategi komunikasi merupakan paduan perencanaan komunikasi dengan manajemen komunikasi untuk mencapai tujuan yang telah ditetapkan. 
Ezra Krisna, Septia Winduwati: Strategi Komunikasi Lembaga Bimbingan Belajar dalam Mempertahankan Loyalitas Pelanggan pada Masa Pandemi (Studi Kasus Pada Bimbel Timothy's)

Berdasarkan pernyataan yang diberikan oleh owner Bimbel Timothy's Sherly Thomas, Bimbel Timothy's telah melakukan perencanaan dengan tujuan mempertahankan pelanggannya pada masa pandemi COVID-19. Strategi yang digunakan oleh Bimbel Timothy's yaitu dengan menambah opsi belajar dengan membuka kelas online. Hal ini ditujukan agar bagi pelanggan yang ingin tetap melakukan kegiatan belajar selama masa pandemi COVID-19 namun merasa takut untuk datang ke Bimbel Timothy's tetap mendapatkan pelayanan dengan menggunakan metode dalam jaringan (daring).

\section{Proses Penyusunan Pesan Bimbel Timothy's pada Masa Pandemi COVID-19}

Dikarenakan terjadinya perubahan metode pembelajaran yang menggunakan daring, maka proses menyusun pesan sangatlah penting yang harus dibentuk oleh Bimbel Timothy's dengan meyakinkan pelanggan bahwa tenaga pengajar telah siap dalam menyampaikan materi melalui jaringan internet. Selain itu untuk kelas tatap muka yang tetap berjalan, Bimbel Timothy's juga harus dapat memberikan kepercayaan kepada pelanggan yaitu dengan menerapkan protokol kesehatan COVID-19 guna mencegah penularan COVID-19, hal ini juga bertujuan agar pelanggan yang ingin tetap anaknya datang ke Bimbel Timothy's tetap merasa aman dan yakin kepada perusahaannya serta tidak menimbulkan kekhawatiran pelanggan. Dalam mengimplementasikannya agar pelanggan dari Bimbel Timothy's mengetahui rencana yang dibuat demi kebaikan bersama, yaitu dengan menginformasikan secara langsung kepada setiap pelanggan Bimbel Timothy's dengan menggunakan telepon, karena dengan menggunakan metode pemberian informasi secara langsung kepada pelanggan merupakan hal yang paling dapat memberikan keyakinan pelanggan terhadap peraturan yang diterapkan selama masa pandemi COVID-19.

Untuk mencapai tujuan yang diharapkan, maka strategi komunikasi harus menunjukkan taktik operasionalnya (Abidin, 2015). Hal tersebut juga diterapkan oleh Bimbel Timothy's yang menjelaskan bahwa kegiatan operasionalnya berubah dari sebelum kegiatan pembelajaran daring. Seluruh kegiatan yang sebelumnya masih dapat dilakukan secara langsung, akhirnya harus membuka kegiatan pembelajaran dalam jaringan. Namun, dari hal tersebut bukan merupakan kendala yang besar yang dihadapi oleh Bimbel Timothy's, karena perusahaan tersebut memiliki pelanggan yang loyal. Oleh karena itu pelanggan Bimbel Timothy's masih tetap stabil walaupun pada masa pandemi COVID-19 seperti sekarang ini.

Sebuah lembaga pendidikan juga harus menetapkan tujuan dan target yang ditentukan melalui komunikasi. Hal tersebut menyebabkan penerapan strategi komunikasi perlu dilakukan dengan berbagai langkah, antara lain dengan mengenal khalayak, menyusun pesan, menetapkan metode, seleksi dan penggunaan media, peranan komunikator, dan evaluasi (Lutfiyah, 2016).

Proses menyusun pesan, yang diartikan sebagai cara merumuskan pesan yang berisi tema dan materi yang membuat pesan tersebut dapat memengaruhi khalayak dan dapat membangkitkan perhatian khalayak. Hal tersebut juga dijalankan oleh Bimbel Timothy's yang menginformasikan bahwa perusahannya memiliki slogan yang berisikan amanat untuk menarik kepercayaan pelanggan terhadap perusahaannya pada masa pandemi COVID-19, yakni dengan slogan "Ayo Lawan COVID-19 Bersama Bimbel Timothy's". Sesuai dengan teori Schramm dalam Yoyon Mudjiono (Luthfiyah, 2016) yang menjelaskan bahwa pesan yang disampaikan harus dapat menarik perhatian pelanggan. Dengan penerapan slogan tersebut menunjukkan 
bahwa Bimbel Timothy's menekankan strategi komunikasinya kepada masyarakat mengenai isu COVID-19 sesuai dengan positioning yang ditetapkan.

\section{Perencanaan Segmentasi Pelanggan Bimbel Timothy's}

Langkah pertama yang harus dilakukan dalam merencanakan segmentasi pelanggan yaitu dengan mengenal khalayak, hal tersebut merupakan cara perusahaan memahami serta mengetahui segmentasi masyarakat yang terbagi atas tiga, yaitu aspek sosiodemografik yang mencakup usia, jenis kelamin, pekerjaan, pendidikan, tingkat pendapatan, agama, ideologi, etnis, serta pemilikan media. Kemudian, aspek psikologis yang mencakup sifat kejiwaan masyarakat antara lain tempramen, tenang, sabar, terbuka, atau tertutup, serta aspek karakteristik perilaku masyarakat yang mencakup kebiasaan yang dijalani dalam kehidupan masyarakat. Antara lain religius, santun, pelit, atau boros. Dalam mencapai target dan tujuan dari Bimbel Timothy's, maka perusahaan ini telah menyusun strategi komunikasi secara sistematis.

Berdasarkan informasi yang diberikan oleh Sherly Thomas dan Novahyanti, Bimbel Timothy's melihat aspek sosiodemografik dan aspek karakteristik perilaku. Karena saat menginformasikan mengenai pangsa pasar dari Bimbel Timothy's kedua narasumber menyatakan bahwa Bimbel Timothy's menyasar pelanggan yang tinggal di daerah Taman Palem Lestari, Taman Surya, dan sekitarnya yang merupakan tempat tinggal dari pelanggannya. Selain itu aspek karakteristik perilaku masyarakat dapat dilihat dari cara Bimbel Timothy's melihat cara pembayaran pelanggannya. Bimbel Timothy's menyasar pelanggan yang memiliki taraf ekonomi menengah hal tersebut menyatakan secara jelas bahwa Bimbel Timothy's juga menggunakan aspek karakteristik perilaku masyarakat dalam menentukan segmentasi masyarakat perusahaannya.

\section{Metode Berkomunikasi yang Ditetapkan Bimbel Timothy's dalam Menjangkau Pelanggannya pada Masa Pandemi COVID-19.}

Setelah menetapkan cara menyusun pesan kepada pelanggannya dan mengetahui segmentasi khalayaknya, langkah selanjutnya yang harus dilakukan yakni dengan menetapkan metode. Dalam melaksanakannya terdapat dua metode antara lain redudancy dan canalizing. Metode redudancy merupakan langkah komunikator dalam membentuk pesan berulang kepada pelanggannya agar pesan yang disampaikan oleh komunikator diikuti oleh pelanggannya. Sebaliknya metode canalizing merupakan langkan komunikator dalam mengidentifikasi pelanggannya untuk mengetahui hal yang diinginkan oleh pelanggannya, lalu melakukan persuasi kepada pelanggan agar dapat mengikuti tujuan yang ditetapkan.

Dalam pelaksanaannya, Bimbel Timothy's menggunakan metode redudancy dalam menetapkan metodenya. Karena menurut Novahyanty, peraturan yang dibuat di Bimbel Timothy's diyakinkan dibuat untuk kebaikan bersama, oleh karena itu seluruh pelanggan yang ingin tetap menjadi keluarga besar Bimbel Timothy's harus dapat mengikuti peraturan yang dibuat, dan peraturan tersebut dibuat berdasarkan keputusan yang telah ditetapkan oleh pemerintah, hal tersebut mengharuskan pelanggan untuk mematuhi seluruh peraturan pemerintah yang juga diterapkan di Bimbel Timothy's.

\section{Saluran dan Peran Media yang digunakan oleh Bimbel Timothy's dalam Menyampaikan Informasi}

Dalam mengimplementasikan strategi komunikasi, maka perusahaan harus 
Ezra Krisna, Septia Winduwati: Strategi Komunikasi Lembaga Bimbingan Belajar dalam Mempertahankan Loyalitas Pelanggan pada Masa Pandemi (Studi Kasus Pada Bimbel Timothy's)

dapat menentukan saluran media yang terbagi atas tiga golongan, yaitu the spoken words, the printed writing, dan the audiovisual media. Ketiganya memiliki peranan penting dalam mengkomunikasikan informasi kepada pelanggannya, namun Bimbel Timothy's hanya menggunakan the printed writing dan the audiovisual media. Hal ini disampaikan oleh Novahyanti yang menyatakan the printed writing digunakan dalam pembuatan poster yang berisikan protokol kesehatan COVID-19 yang juga tercetak slogan yang diterapkan oleh Bimbel Timothy's selama pandemi COVID-19 yaitu "Ayo Lawan COVID-19 Bersama Bimbel Timothy's" dan the audiovisual media yang digunakan yaitu dengan membuat video mengenai protokol kesehatan yang diterapkan. Antara lain dengan menjelaskan hal-hal yang dilakukan oleh seluruh individu yang bekerja di Bimbel Timothy's dan pelanggan tetap yang telah menjadi bagian dari Bimbel Timothy's bahwa di dalam perusahaan ini telah menerapkan protokol kesehatan yang sesuai dengan perintah yang diinstruksikan oleh pemerintah.

Poster serta video yang dibuat oleh Bimbel Timothy's tersebut diunggah melalui akun media sosial Instagram yang mendapatkan respon positif dari pelanggan, dikarenakan hal tersebut nampak membantu kestabilan dari kondisi ekonomi dari Bimbel Timothy's pada masa pandemi COVID-19 yang disebabkan kepercayaan pelanggan yang tetap terjaga.

\section{Peranan Owner dan Manajer Bimbel Timothy's dalam Lembaga Bimbel Timothy's pada saat Pandemi COVID-19}

Proses penentuan strategi komunikasi berikutnya yakni dengan mengetahui peranan komunikator yang berada di dalam perusahaan tersebut, karena kepercayaan komunikan terhadap komunikator sangat berpengaruh terhadap efek pesan yang disampaikan oleh komunikator. Pada Bimbel Timothy's setiap individu yang terlibat dalam penugasan pada masa pandemi COVID-19 memiliki perannya masing-masing.

Peranan tersebut dijalankan antara lain, Sherly Thomas sebagai owner dari Bimbel Timothy's memiliki peranan dalam merencanakan cara memberikan pelayanan terbaik kepada pelanggannya agar tetap percaya kepada perusahannya walau sedang dalam masa pandemi COVID-19 berlangsung. Hal yang berbeda yakni Novahyanti sebagai manajer dari Bimbel Timothy's memiliki peranan dalam melakukan kontrol terhadap penerapan protokol kesehatan yang akan dijadikan bahan evaluasi pada saat berjalannya strategi yang dijalankan selama pandemi COVID-19.

\section{Cara Evaluasi Strategi Komunikasi Bimbel Timothy's}

Setelah mengetahui peranan komunikator, langkah akhir yang harus dilakukan oleh perusahaan yakni dengan melakukan evaluasi. Cara mengevaluasi terbagi atas dua yakni evaluasi program dan evaluasi manajemen. Evaluasi program dilakukan untuk melihat sejauh mana tujuan tersebut ingin dicapai, sedangkan evaluasi manajemen merupakan hasil dari pencapaian operasional. Bimbel Timothy's dalam mengevaluasi strategi komunikasi yang dibuat yaitu dengan melakukan evaluasi manajemen dikarenakan fokus terhadap pencapaian operasional kegiatan yang berada di perusahaannya.

Sesuai dengan yang dinyatakan oleh Novahyanti, bahwa evaluasi yang dilakukan yaitu dengan cara melakukan meeting terkoordinasi kepada guru sebagai tenaga pengajar di kelas masing-masing yang langsung berhubungan dengan pelanggan mengenai kekurangan yang ditemukan dalam proses penerapan strategi 
yang dibentuk oleh Bimbel Timothy's yang dapat memengaruhi kepercayaan pelanggan pada masa pandemi COVID-19 sehingga berpengaruh bagi loyalitasnya terhadap Bimbel Timothy's.

\section{Tujuan Implementasi Program Strategi Komunikasi pada Masa Pandemi COVID-19}

Berdasarkan Effendy (2011), tujuan strategi komunikasi yakni to secure understanding yang mengupayakan komunikan mengerti pesan yang disampaikan komunikator, lalu to establish acceptance yaitu membina komunikan atas pesan yang disampaikan oleh komunikator, dan to motivate action yaitu untuk menggerakkan komunikan agar dapat melakukan tindakan sesuai dengan yang diinginkan oleh komunikator.

Bimbel Timothy's dalam menerapkan strategi komunikasinya telah memenuhi tujuan dari hal yang harus dilakukannya dalam membuat pelanggannya sesuai dengan yang ditujukan atau ditargetkan oleh Bimbel Timothy's. Hal ini sejalan dengan yang dijelaskan oleh Novahyanti sebagai manajer dari Bimbel Timothy's. Menurutnya dalam sebuah perusahaan harus melakukan secure understanding. Di Bimbel Timothy's menyebarkan formulir kepada pelanggannya dengan menanyakan kesediaannya dalam menandatangani formulir tersebut bahwa pelanggan dari Bimbel Timothy's tersebut telah mengerti hal-hal yang harus dipatuhi oleh pelanggannya untuk mengikuti peraturan yang ditetapkan di Bimbel Timothy's selama pandemi COVID-19 dengan mengikuti seluruh protokol kesehatan.

Selain itu juga perushaan harus melakukam establish acceptance yaitu dengan menginformasikan kepada pelanggannya bahwa protokol yang diterapkan masih berjalan sesuai dengan rencana yang dijalankan, yaitu dengan mengkomunikasikannya melalui video yang dibagikan secara terus-menerus melalui Instagram Story, Instagram Feeds dan WhatsApp. Serta to motivate action, yaitu dengan menerapkan seluruh kegiatan protokol kesehatan seperti melakukan pengecekan suhu tubuh, mengharuskan penggunaan masker dan face shield serta menyediakan hand sanitizer sehingga membuat pelanggannya menjadi percaya untuk menitipkan anaknya di Bimbel Timothy's.

\section{Loyalitas Pelanggan Bimbel Timothy's}

Perilaku word of mouth sangat berdampak bagi emosional yang signifikan dalam membangun loyalitas pelanggan menurut Dick \& Basu, dalam Tjiptono (2014) oleh sebab itu perusahaan harus dapat mempertahankan loyalitas pelanggan dengan cara yang tepat agar konsumen dapat berubah menjadi klien pada perusahaan tersebut.

Sesuai dengan yang dinyatakan oleh Sherly Thomas yang menyatakan bahwa perilaku word of mouth sangat memengaruhi Bimbel Timothy's seperti contoh ia memiliki pelanggan yang memiliki tiga anak, saat anak pertamanya masuk ke Bimbel Timothy's dan pelanggannya telah cocok dengan perusahaannya, lalu pelanggan tersebut merekomendasikan anak kedua dan ketiganya untuk bergabung ke dalam Bimbel Timothy's juga.

Selain itu dinyatakan juga oleh Novahyanti, bahwa terdapat pelanggan yang loyal terhadap perusahaannya seperti contoh ia sebagai manajer kerap mendapatkan pesan dari calon pelanggannya bahwa calon pelanggannya tersebut direkomendasikan oleh pelanggan tetapnya. Hal tersebut sangat berpengaruh bagi 
Ezra Krisna, Septia Winduwati: Strategi Komunikasi Lembaga Bimbingan Belajar dalam Mempertahankan Loyalitas Pelanggan pada Masa Pandemi (Studi Kasus Pada Bimbel Timothy's)

kestabilan perekonomian di dalam internal Bimbel Timothy's terlebih pada saat masa pandemi COVID-19 agar tetap dapat survive pada masa krisis tersebut.

\section{Teknik Word of Mouth Pelanggan Bimbel Timothy's pada Masa Pandemi COVID-19}

Dalam mempertahankan loyalitas pelanggan maka perusahaan harus menciptakan hubungan dengan pelanggan dengan cara yang benar. Pelanggan yang telah memiliki loyalitas terhadap suatu perusahaan harus dipertahankan dan diarahkan untuk menjadi klien dari perusahaan tersebut. Pada tahap ini, perusahaan telah berhasil mengubah pelanggan menjadi klin. Cara perusahaan agar dapat menarik pelanggan tersebut menjadi klien yaitu dengan cara menawarkan produk yang diciptakan oleh suatu perusahaan secara berkelanjutan. Hal tersebut didukung, karena pelanggan di Bimbel Timothy's telah merekomendasikan Bimbel Timothy's kepada temannya yang dapat menggambarkan bahwa pelanggan tersebut merupakan pelanggan yang loyal dengan menggunakan teknik word of mouth dalam menyampaikan pesannya seperti yang dinyatakan oleh Rizky Aditya Wardhana selaku pelanggan yang telah menjadi pelanggan tetap di Bimbel Timothy's.

\section{Simpulan}

Berdasarkan dari hasil penelitian yang dilakukan, maka kesimpulan dari penelitian Strategi Komunikasi Lembaga Bimbingan Belajar dalam Mempertahankan Loyalitas Pelanggan pada Masa Pandemi COVID-19 (Studi Kasus pada Bimbel Timothy's, Cengkareng, Jakarta Barat) antara lain sebagai berikut:

1. Perencanaan strategi komunikasi yang dilakukan oleh Bimbel Timothy's yaitu dengan mengenal khalayak perusahaannya yang berbasis pada aspek sosiodemografik dan aspek karakteristik perilaku masyarakat. Selain itu pada masa pandemi COVID-19 ini, cara Bimbel Timothy's menyusun pesan dengan menarik perhatian pelanggan dan metode yang ditetapkan yaitu dengan membuat pelanggannya mengikuti strategi yang ditetapkan dengan membuat slogan "Ayo Lawan COVID-19 bersama Bimbel Timothy's".

2. Pengimplementasian strategi komunikasi yang dilakukan oleh Bimbel Timothy's yaitu menggunakan media sosial sebagai sarana penyampaian pesan dengan tujuan dapat menginformasikan kepada pelanggan terkait jasa yang ditawarkan dalam rangka mempertahankan loyalitas pelanggan.

3. Proses evaluasi yang dilakukan oleh Bimbel Timothy's yaitu dengan melakukan evaluasi manajemen yang dilakukan untuk mengevaluasi strategi komunikasi yang diterapkan pada masa pandemi COVID-19.

4. Kekhususan strategi komunikasi Bimbel Timothy's dalam menginformasikan pelanggannya yakni dengan menerapkan kebijakan terkait pengajar yang bersedia untuk mengajarkan siswanya hingga materi yang dipelajari dapat dipahami secara keseluruhan.

\section{Ucapan Terima Kasih}

Ucapan terima kasih peneliti berikan kepada Ibu Septia Winduwati S.Sos., M.Si. selaku dosen pembimbing skripsi peneliti. Selain itu kepada Sherly Thomas, Novahyanty, Felice Ferina, dan Rizky Aditya Wardhana sebagai narasumber yang memberikan informasi kepada peneliti sehingga dapat menyelesaikan hasil penelitian 
ini. Selain itu ucapan terima kasih juga kepada orang tua peneliti yaitu Teddy Kurniawan dan Joe We Ing Ineke Julianti, serta orang-orang yang berjasa yang telah membantu peneliti menyelesaikan hasil penelitian ini.

\section{Daftar Pustaka}

Abidin, Y. Z. (2015). Manajemen Komunikasi (Filosofi, Konsep, dan Aplikasi). Bandung: Pustaka Setia.

Effendy, O. U. (2011). Ilmu Komunikasi: Teori dan Prakteknya. Bandung: Remaja Rosdakarya

Luthfiyah, Lenny. (2016). Strategi komunikasi Women's Crisis Center (WCC) Jombang dalam Mewujudkan Masyarakat Adil Gender (dalam tinjauan teori konstruktivisme Jesse Delia). Skripsi, Universitas Islam Negeri Sunan Ampel Surabaya

Masuroh. (2020). Strategi Komunikasi Pemasaran Toserba Laris Kartasura dalam Meningkatkan Loyalitas Pelanggan. Surakarta: Institut Agama Islam Negeri

Tjiptono, Fandy. (2014). Pemasaran Jasa (Prinsip, Penerapan, Penelitian). Yogyakarta: ANDI

Savitri, L., Setyanto, Y., \& Winduwati, S. (2016). Strategi Public Relations dalam Membangun Brand Image Eco-Tourism Pulau Lombok. Bachelor Thesis, Universitas Tarumanagara

Susanto, A. (2018). Bimbingan dan Konseling di Sekolah Konsep, Teori, dan Aplikasinya. Jakarta: Prenada Media Group. 